Wu, Q., et al., 2021, High-precision U-Pb age constraints on the Permian floral turnovers, paleoclimate change, and tectonics of the North China block: Geology, v. 49, https://doi.org/10.1130/G48051.1

\title{
The Supplementary Information includes:
}

S1. Stratigraphy of the studied sections and geochronologic sampling

\section{S2. Previous geochronology}

$\mathrm{S3}$. $\mathrm{U}-\mathrm{Pb}$ analytical procedures, data reduction, age calculation, and interpretation

\section{S4. Bayesian age-stratigraphic model}

\section{References cited}

Fig. DR1 Stratigraphic columns of the study sections

Fig. DR2 Outcrop photos of the sections and microscope image of zircon crystals

Fig. DR3 Relative possibility diagram of the reported detrital zircon ages

Fig. DR4 Zircon U-Pb concordia and weighted mean ${ }^{206} \mathrm{~Pb} /{ }^{238} \mathrm{U}$ dates diagrams

Fig. DR5 Bchron age-depth model with 95\% confidence level uncertainty

Table DR1 Common lithostratigraphic nomenclature of the Carboniferous-Permian formation names in North China.

Table DR2 Analyses of detrital zircon LA-ICPMS U-Pb data in Ma et al. (2014)

Table DR3 SIMS U-Pb data for analyzed zircons from sample NC-16

Table DR4 U-Pb isotopic data for CA-ID-TIMS zircon analyses 


\section{S1. Stratigraphy of the studied sections and geochronologic sampling}

The main studied sections are located in the northern North China Block. The Palougou and the Qiaotou sections are approximately $20 \mathrm{~km}$ apart and are located in the northwestern Shanxi Province (Baode County) near the eastern banks of the Yellow River (Fig. 1B). The Sigou Section is located $144 \mathrm{~km}$ to the southeast of the Palougou Section (Fig. 1B), within the Western Shanxi (Jinxi) fold belt (Tang et al., 2012). The Palougou and Sigou sections expose all five Permian formations, which in ascending order include the Taiyuan, Shansi, Lower Shihhotse, Upper Shihhotse, and Sunjiagou formations (Fig. DR1A). The Qiaotou Section exposes a more complete succession of the Shansi Formation, which is regarded as an auxiliary section for the Shansi Formation at the Palougou Section (Fig. DR1D).

The Pennsylvanian-Permian deposits are laterally continuous throughout the North China Block, although different lithostratigraphic nomenclature has been applied to these deposits across the region (Table DR1). The Taiyuan and Shansi formations are interpreted as alternating marine and terrestrial units mainly deposited in epeiric sea to paralic swamp environments (Lee, 1986; Liu, 1990; Lv and Chen, 2014). The Taiyuan Formation mainly consists of siltstone, mudstone, black shale, and coal seams, interbedded with several marine limestone beds. Abundant fusulinid and a few conodont fossils were reported from these limestones (Kong et al., 1996; Wang and Qi, 2003 and references therein; Shen et al., 
2019b). The Shansi Formation overlies conformably the Taiyuan Formation, with a thick layer of yellowish-gray, quartz pebble sandstone marking the boundary. The coal-bearing Shansi Formation has a similar lithologic composition with that of the Taiyuan Formation, except that it lacks marine limestone beds.

The Lower Shihhotse and the Upper Shihhotse formations are mainly composed of fluvial sediments. The base of the Lower Shihhotse Formation is characterized by a thickbedded yellowish-gray pebbly quartz sandstone. The Lower Shihhotse Formation is dominated by yellowish-gray, coarse to medium-grained sandstone and gray mudstone with a few coal beds in the lower part. The boundary between the Lower Shihhotse and the Upper Shihhotse formations is marked by a set of thick-bedded grayish-yellow, lithic sandstones. The Upper Shihhotse Formation is thick and divided into two parts. The lower part mainly consists of yellowish-gray, pebbly quartz sandstone and mudstone. The upper part is dominated by reddish-brown and greenish-grey (mottled) mudstone and fine sandstone (Liu et al., 2015). Ferruginous argillic Gleysols and Argillisols, as well as channel-fill sandstones are abundant in the upper part of the Upper Shihhotse Formation (Figs. DR1B, DR2D).

The overlying Sunjiagou Formation starts with a thick layer of yellowish-gray sandstone, containing conglomerates and crossbeds (Figs. DR2A, C). It is characterized by an interval of red to purple, fine sandstone and mudstone. They are interbedded with gray 
feldspathic quartz sandstone, which are interpreted to have been deposited in meandering streams. Gypsum, calcite breccias and aeolian sandstone in the basal part of the Sunjiagou Formation indicate a typical arid condition (Norin, 1924; Wang, 1993; Stevens et al., 2011). The top of the Sunjiagou Formation is approximately correlated with the Permian-Triassic boundary (Wang, 1993; Chu et al., 2015, 2019, Zhu et al., 2019).

A total of 11 samples of bentonite and tuffaceous mudstones were collected from three sections for $\mathrm{U}-\mathrm{Pb}$ geochronological analysis (Tables 1 and DR4). Eight samples were collected from the Palougou Section (Fig. DR1A). Sample NC-3 was collected from a 5 mm-thick, yellowish-gray, bentonite layer, bound by two marine limestone beds in the middle interval of the Taiyuan Formation at the Palougou Section (Fig. DR2I). The lower limestone bed named the Palougou Limestone is correlated to the Wujiayu Limestone of the classic succession in Taiyuan City, Shanxi Province. This limestone occurs about 15.5 $\mathrm{m}$ below the NC-3 bentonite and contains abundant fusulinid fossils, including Triticites, Montiparus, Pseudofusulina, and Schwagerina (Kong et al., 1996). This fusulinid assemblage is correlated to the Triticites Biozone at the Yangchang Section in Guizhou, South China, which is considered of Gzhelian Age (Late Carboniferous) (Sheng and Jin, 1994). The Palougou Limestone yielded conodonts as well, including Streptognathodus oppletus, S. elegantulus, and Idiognathodus hebeiensis (Wan and Ding, 1987; Kong et al., 1996), which are also correlative to those in the Guizhou area substantiating the Gzhelian 
Age (Wang and Qi, 2003). The upper limestone bed, named the Baode Limestone, correlated to the Maoergou Limestone of the classic successions in Shanxi Province (Kong et al., 1996), lies about $16 \mathrm{~m}$ above the NC-3 bentonite. Several other limestone beds occur above the Maoergou Limestone in the Taiyuan Formation in Taiyuan, Shanxi Province. These limestones show no obvious differences in fossil content, which is dominated by conodonts Streptognathodus barskovi together with S. isolatus, , as well as the fusulinid Pseudoschwagerina (Kong et al., 1996; Wang and Qi, 2003). Both the conodonts and the fusulinids indicate an Asselian Age (Cisuralian) ( Henderson, 2018; Shen et al., 2019b) although some of the Streptognathodus taxa need to be reevaluated. Sample NC-4 was collected from a $5 \mathrm{~cm}$-thick yellowish-gray tuffaceous bed near the top of the Taiyuan Formation at the Palougou Section (Fig. DR2J). The Upper Shihhotse Formation samples start with BD082919-1, a 7-12 cm-thick, greenish-grey bentonite from the lower massive sandstone interval and about $20 \mathrm{~m}$ above the base of the formation (Fig. DR2H). Further up-section, samples BD-3 and $\mathrm{NC}-16$ were collected from the same tuff layer, but in different locations within the red beds (Fig. DR2F). Sample BD-2 was collected from a clay-rich bed, which is stratigraphically $68 \mathrm{~m}$ higher than BD-3. Sample BD083019-2 is a 5-8 cm-thick, greenish-white bentonite collected from $9 \mathrm{~m}$ above BD-2 (Fig. DR2G). About $10 \mathrm{~m}$ higher in the section, Sample NC-11 was collected from about $10 \mathrm{~m}$ below the base of the overlying Sunjiagou Formation. Despite a poor fossil record, several studies based on $\mathrm{U}-\mathrm{Pb}$ zircon geochronology by the laser ablation-inductively coupled plasma- 
mass spectrometry (LA-ICP-MS) have attempted to constrain the maximum depositional age of the Upper Shihhotse Formation (see below).

Two closely spaced bentonite layers, $3.1 \mathrm{~m}$ apart, were sampled from the coal beds assigned to the Shansi Formation at the Qiaotou Section (Figs. DR1D, DR2K). Sample BD-5 is from a $6 \mathrm{~cm}$-thick gray bentonite layer within the coal and Sample NC-8-2 from a $4 \mathrm{~cm}$-thick greyish-white bentonite, immediately below massive sandstone of the Shansi Formation. In addition to other thin ash beds, several charcoal layers are interbedded in the Shansi Formation at the Qiaotou Section, which have been interpreted as wildfire residues (Yan et al., 2016).

Sample SG-18-D-05 was collected from a $3 \mathrm{~cm}$-thick greenish-grey tuffaceous bed in the base of the Sunjiagou Formation at the Sigou Section (Fig. DR1). Considering that the basal Sunjiagou Formation overlies an unconformity and that the Sigou Section is more than $140 \mathrm{~km}$ distant from the Palougou Section, the correlation between the two sections is not well constrained. Nevertheless, the plant fossil Lepidopteris from the lower part of this unit indicates a Lopingian age (Zhang et al., 2012). Furthermore, investigations on the Sunjiagou Formation from about twenty localities in Shanxi, Shaanxi, Henan and Hebei provinces in North China have yielded the Ullmannia bronnii-Yuania magnifolia plant fossil assemblage without obvious variations and thus confirm a Lopingian age for the formation (Wang and Wang, 1987, Wang, 2010). 


\section{S2. Previous geochronology}

Radioisotopic ages from the Permian outcrop successions in North China have been limited to a few $\mathrm{U}-\mathrm{Pb}$ zircon studies by in-situ analyses on tuffs or tuffaceous sedimentary beds, as well as detrital zircon provenance studies on sandstones (e.g., Li et al., 2010; Zhu et al., 2014; Yang et al., 2017). A U-Pb zircon age of $290.1 \pm 5.8 \mathrm{Ma}(\mathrm{MSWD}=0.58, \mathrm{n}=$ $5,95 \%$ confidence) by the secondary ion mass spectrometry (SIMS) method was reported by Cope et al. (2005) from a highly altered and strongly reworked ash bed above the thick coal beds in the northern margin of the North China Block, correlative to those of the Taiyuan and/or Shansi formations. Another U-Pb SIMS age of $296 \pm 4 \mathrm{Ma}(\mathrm{MSWD}=3.3$, $\mathrm{n}=14,95 \%$ confidence) was reported by Zhang et al. (2007) from a volcanic tuff bed in the Hongmiaoling Formation in western Beijing, which was roughly correlated with the Lower Shihhotse and Upper Shihhotse formations. Yang et al. (2014) reported an age of $293.0 \pm 2.5 \mathrm{Ma}(\mathrm{MSWD}=0.57, \mathrm{n}=21,95 \%$ confidence $)$ by the LA-ICP-MS technique from a tuffaceous sandstone in the upper part of the Shansi Formation in southeastern North China. Although the above geochronology pointed to a Cisuralian age for much of the Permian succession in North China, they were unable to resolve its outstanding chronostratigraphic issues for the following reasons. First, the low precision of the U-Pb analyses by in situ techniques (internal uncertainties of $1 \%$ or more on individual analyses, and up to $4 \%$ external uncertainties) cannot fully distinguish zircons of mixed-age 
populations in a tuffaceous rock (e.g., Schmitz and Kuiper, 2013). Second, untreated zircons used in in-situ analyses can be compromised by Pb-loss, which can have a significant effect on the accuracy of the U-Pb dates (e.g., Schaltegger et al., 2015; Wu et al., 2017). Third, the age results of Cope et al. (2005) and Zhang et al. (2007) were from units in the marginal areas of the North China Block, with ambiguous correlations to the classic Permian successions in the Shanxi Province, central North China Block.

The depositional age of the Upper Shihhotse Formation, in particular, has been controversial. We have compiled previously reported detrital zircon geochronology by the LA-ICP-MS method from the Upper Shihhotse Formation and the base of the Sunjiagou Formation across North China, based on the works of Yang et al. (2006), Liu et al. (2014), Zhu et al. (2014), Luo et al. (2017), Wang et al. (2019), Zhu et al. (2019) and Sun et al. (2020) (Fig. DR3). The relative probability diagram of Fig. DR3 distinguishes between the youngest populations of analyzed zircons (based on 3 or more overlapping analyses) and the single youngest zircon age of each study marked by the arrow. Deriving depositional age constraints from the single youngest analysis, which is likely to be affected by the substantial $\mathrm{Pb}$-loss, can lead to grossly underestimated age estimates. This is particularly alarming in the case of data obtained by the in-situ technique (LA-ICP-MS or SIMS), which lacks the chemical abrasion pre-treatment necessary to overcome the effects of $\mathrm{Pb}$ loss (e.g., Wu et al., 2017). More conservative approaches to age calculation involving 
youngest statistical population of multiple analyses tend to produce relatively more accurate maximum depositional ages as they are less susceptible to open system behavior in individual zircons (Coutts et al., 2019).

The limitations of in-situ analytical techniques in producing meaningful depositional age constraints from the non-marine Permian are apparent in the LA-ICP-MS results, e.g., the age data in Ma et al. (2014) for the northern North China Craton (Table DR2). Here the calculated weighted mean ages ( $2 \sigma$ internal errors) from the youngest zircon populations for the Lower Shihhotse Formation $(258.0 \pm 4.1 \mathrm{Ma}, \mathrm{n}=28)$ and the Sunjiagou Formation $(254.1 \pm 9.5 \mathrm{Ma}, \mathrm{n}=2)$ overlap within uncertainty, even though the corresponding sampled beds (XSH and SQF) are ca. 200 meters apart in stratigraphy (Fig. 5 in Ma et al., 2014). A closer look at the XSH data reveals that the single youngest analysis was $238 \pm 24 \mathrm{Ma}$ and the next five youngest analyses all overlap with the Permian-Triassic boundary within uncertainty. The obvious conflict with stratigraphy might suggest the inaccuracy of the estimated ages for other units due to extensive $\mathrm{Pb}$ loss in analyzed zircons.

If the single youngest zircons are excluded from the detrital zircon age estimates, the bulk of previously reported geochronology constrained the maximum depositional ages of the Upper Shihhotse Formation to $c a$. 275-280 Ma and the basal Sunjiagou Formation to ca. 255-269 Ma, which reveals an age gap (Fig. DR3) and approaches the high-precision geochronologic results of this study (see below). The emerging depositional age gap 
between the two units (Fig. DR3) is expected to be of variable duration depending on proximity to the orogenic front in the north. Also, craton-wide lithostratigraphic correlations based on presence or absence of coal beds and massive sandstone beds would likely result in diachronous formation boundaries. For example, the youngest detrital zircon age clusters from Ma et al. (2014) revealed a longer age gap (ca. 300 Ma-260 Ma) between the Shansi and Lower Shihhotse formations.

Recent U-Pb geochronology by the CA-ID-TIMS method of tuff beds in the subsurface (Yang et al., 2020) has provided excellent age constraints for Penchi and Taiyuan formations in southeastern North China Block.

\section{S3. U-Pb analytical procedures, data reduction, age calculation, and interpretation}

\section{$\underline{\text { S3.1. U-Pb SIMS geochronology }}$}

Fifty-one SIMS U-Pb analyses were carried out on zircons from Sample NC-16 as an age pre-screening scheme prior to CA-ID-TIMS analyses. The zircons from NC-16 together with the zircon standard Qinghu were cast in a transparent epoxy mount. The mount was then polished to expose the interior of crystals for analyses. All zircons were documented with transmitted and reflected light photo-microscopy to select zircon domains that are free of inclusions or cracks. Cathodoluminescence images were taken to 
reveal the internal zoning and select the appropriate domains of the zircon crystals. The mount was vacuum-coated with high purity gold before SIMS analyses. U, Th and $\mathrm{Pb}$ isotopes were measured on a Cameca IMS 1280 SIMS at the Institute of Geology and Geophysics, Chinese Academy of Sciences in Beijing, China. The analysis spot sizes are ca. $20 \mu \mathrm{m} \times 30 \mu \mathrm{m}$. The detailed analysis procedures have been described in Li et al. (2009). Analyses of zircon standard Qinghu were interspersed with the unknowns. The average of present-day crustal $\mathrm{Pb}$ isotopic composition of Stacey and Kramers (1975) was used for common $\mathrm{Pb}$ correction assuming that the common $\mathrm{Pb}$ is largely surface contamination resulting from sample preparation. The SIMS data were reduced by using Isoplot 3.75 (Ludwig, 2012). The sample date is calculated based on the weighted mean ${ }^{206 \mathrm{P}} \mathrm{b} /{ }^{238} \mathrm{U}$ date of the youngest population of zircons that overlaps within $2 \sigma$ internal (analytical) uncertainty. The detailed U-Pb isotopic data and ages by the SIMS method can be seen in

\section{Table DR3.}

The data from the Qinghu zircon standards yielded a weighted mean ${ }^{206 \mathrm{P}} \mathrm{b} /{ }^{238} \mathrm{U}$ date of $159.9 \pm 1.1 \mathrm{Ma}(\mathrm{n}=18, \mathrm{MSWD}=0.74)$, which is within error of the recommended age of $159.38 \pm 0.12$ Ma by the CA-ID-TIMS method (Li et al., 2009). Except for four analyses with high common $\mathrm{Pb}$, the other 47 analyses gave indistinguishable ${ }^{206 \mathrm{P}} \mathrm{b} /{ }^{238} \mathrm{U}$ ratios within analytical errors and yielded a weighted mean ${ }^{206 \mathrm{P}} \mathrm{b} /{ }^{238} \mathrm{U}$ date of $282.1 \pm 1.2 \mathrm{Ma}$ (MSWD $=0.53,95 \%$ confidence interval, Fig. DR4 B). 


\section{S3.2. U-Pb CA-ID-TIMS geochronology}

Seventy six single zircon grains from eleven bentonite or tuffaceous mudstone samples collected from three stratigraphic sections were analyzed for $\mathrm{Pb}$ and $\mathrm{U}$ isotopes by the CA-ID-TIMS technique at the Massachusetts Institute of Technology Isotope Laboratory. Samples were on the order of 2 to $5 \mathrm{~kg}$ in weight and were processed by soaking in water for 48 hours, followed by complete liquefaction in a blender. Sand-size grains were separated from the clay matrix in a sonic dismembrator device designed by Hoke et al. (2014). Heavy-mineral concentrates were achieved through step-wise magnetic as well as high-density liquid separation techniques. The final zircon selection was carried out under a binocular microscope.

The majority of samples contained mixed populations of zircons ranging from subrounded to multi-faceted prisms. The prismatic or acicular zircon grains containing elongate glass (melt) inclusions parallel to their long axis are shown to represent the youngest population of zircons in the samples (Ramezani et al., 2011) and were targeted for our analyses. The selected grains were pre-treated by a chemical abrasion (CA) technique modified after Mattinson (2005). Chemical abrasion was achieved by thermal annealing at $900{ }^{\circ} \mathrm{C}$ for 60 hours, followed by leaching in $29 \mathrm{M} \mathrm{HF}$ inside high-pressure vessels at $210{ }^{\circ} \mathrm{C}$ for 11.5 to 12 hours. The leached grains were fluxed in several hundred microliters of dilute $\mathrm{HNO}_{3}$ and $6 \mathrm{M} \mathrm{HCl}$, successively on the hot plate and in an ultrasonic 
bath (1 hour each step), and rinsed with several volumes of Millipore water in between to remove the leachates. The thoroughly rinsed grains were spiked with the EARTHTIME ET535 mixed ${ }^{205} \mathrm{~Pb}_{-}{ }^{233} \mathrm{U}_{-}{ }^{235} \mathrm{U}$ tracer (Condon et al., 2015; McLean et al., 2015) prior to complete dissolution in $29 \mathrm{M} \mathrm{HF}$ at $210{ }^{\circ} \mathrm{C}$ for 45 to 48 hours. The dissolved $\mathrm{U}$ and $\mathrm{Pb}$ were chemically purified using $50 \mu \mathrm{l}$ columns of AG1X-8 anion-exchange resin. The purified $\mathrm{U}$ and $\mathrm{Pb}$ were finally loaded together onto degassed $\mathrm{Re}$ filaments mixed with a silica gel emitter solution and their isotopic ratios were measured on an Isotopx X62 multicollector thermal ionization mass spectrometer equipped with a Daly photomultiplier ion counting system. $\mathrm{Pb}$ isotopes were measured as mono-atomic ions on a single ion-counter and were corrected for a mass-dependent isotope fractionation of $0.18 \% \pm 0.05 \%$ per atomic mass unit $(2 \sigma)$. $\mathrm{U}$ isotopes were measured as dioxide ions simultaneously using three Faraday collectors, while subjected to a within-run mass fractionation correction using the ${ }^{233} \mathrm{U} /{ }^{235} \mathrm{U}$ ratio of the tracer and a predicted sample ${ }^{238} \mathrm{U} /{ }^{235} \mathrm{U}$ ratio of $137.818 \pm$ 0.045 (Hiess et al., 2012). An oxide correction based on an independently determined ${ }^{18} \mathrm{O} /{ }^{16} \mathrm{O}$ ratio of $0.00205 \pm 0.00005$ was also applied to the measured $\mathrm{U}$ isotopic rations.

Data reduction, error propagation and $\mathrm{U}-\mathrm{Pb}$ date calculation were carried out using the Tripoli and ET_Redux algorithms (Bowring et al., 2011; McLean et al., 2011). Complete $\mathrm{Pb}$ and $\mathrm{U}$ isotopic data by the CA-ID-TIMS method are given in Table DR4. Sample dates representing zircon crystallization ages are calculated based on the weighted 
mean ${ }^{206} \mathrm{~Pb} /{ }^{238} \mathrm{U}$ dates derived from the coherent clusters of the youngest zircon analyses in each sample, after excluding resolvably older analyses interpreted reworked or detrital. Weighted mean date uncertainties are reported at $95 \%$ confidence level in the $\pm \mathrm{X} / \mathrm{Y} / \mathrm{Z}$ format, where $\mathrm{X}$ is the $2 \sigma$ internal (analytical) uncertainty exclusive of all external errors, $\mathrm{Y}$ incorporates the $\mathrm{U}-\mathrm{Pb}$ tracer calibration error, and $\mathrm{Z}$ includes $\mathrm{Y}$ as well as the $\mathrm{U}$ decay constant errors of Jaffey et al. (1971). Calculated weighted mean dates and their uncertainties are given in Table 1 and illustrated in the date distribution plots of Figure DR4. A calculated weighted mean date is interpreted as the maximum age of deposition for the corresponding bed. A set of high-resolution $\mathrm{U}-\mathrm{Pb}$ dates from closely spaced ash beds that obey the stratigraphic order provide reliable estimates of the true depositional age.

Samples NC-3, NC-4, BD082919-1, BD-3, NC-16 and BD083019-2 from the Palougou Section, as well as BD-5 and NC-8-2 from the Qiaotou Section, all produced statistically robust weighted mean ${ }^{206} \mathrm{~Pb} /{ }^{238} \mathrm{U}$ dates that are consistent with stratigraphic superposition (Fig. DR1). The dates of NC-16 and BD-3 are consistent with each other within analytical error (Fig. DR4 A). Here, the date of BD-3 was taken into discussion and used in the age-depth model calculation. Results from the samples in the Taiyuan Formation are also consistent with the Carboniferous-Permian marine biostratigraphy. For samples NC-11 (Palougou Section) and SG-18-D-05 (Sigou Section), scatter in data due to extensive detrital input prevented the calculation of a statistically meaningful weighted 
mean date. Nevertheless, the age of the single youngest zircon from each of these two samples is consistent with stratigraphy and thus can be used to estimate the maximum age of deposition.

The only exception is Sample BD-2 from the Palougou Section, whose youngest four analyses $(267.99 \pm 0.20 \mathrm{Ma}$ to $259.58 \pm 0.17 \mathrm{Ma})$ are up to $20 \mathrm{~m} . \mathrm{y}$. younger than its predicted age based on the adjacent BD-3, BD083019-2 and NC-11 dates from the same section. Based on its physical characteristics of a paste-like, clay-rich layer and its outcrop exposures as a subhorizontal bed near the water level of a present-day creek, it is likely that the BD-2 zircons originated from topographically higher exposures (e.g., Sunjiagou Formation strata) and subsequently embedded in the sample site by modern stream flows.

Four zircon grains from Sample NC-16, which had been analyzed by the U-Pb SIMS method (zs08, zs12, zs42 and zs44) and produced the youngest ages ( $c a .274$ Ma to 278 $\mathrm{Ma}$ ), were subsequently removed from the grain mount and reanalyzed by the CA-IDTIMS technique (Figs. DR4A, B). They yielded CA-ID-TIMS dates of $283.92 \pm 1.15 \mathrm{Ma}$, $284.04 \pm 0.46 \mathrm{Ma}, 284.02 \pm 0.39 \mathrm{Ma}$ and $283.32 \pm 0.48 \mathrm{Ma}$, respectively. These (excluding zs44), combined with another six CA-ID-TIMS zircon analyses from NC-16 yield a weighted mean ${ }^{206} \mathrm{~Pb} /{ }^{238} \mathrm{U}$ date of $284.04 \pm 0.10 / 0.18 / 0.35 \mathrm{Ma}(\mathrm{n}=9, \mathrm{MSWD}=0.25)$ (Fig. DR4 A). The slightly younger weighted mean age from the SIMS method along with the resolvably younger CA-ID-TIMS age of zs44 point out to the effects of persistent Pb-loss, which is more pronounced in the untreated (by chemical abrasion) SIMS analyses. 
The large number of zircon analyses from Sample NC-16 by both methods and the lack of any significant age outliers strongly suggest that the tuff layer of NC-16 (and BD3) from the Upper Shihhotse Formation was a primary volcanic ash bed, which is unlikely to contain reworked material from an older volcanic source. These results further support a Cisuralian depositional age for the Upper Shihhotse Formation.

\section{S4. Bayesian age-stratigraphic model}

In this study we use a Bayesian interpolation statistical algorithm to construct an agestratigraphy model for the Cisuralian strata in Baode area, Shanxi Province to provide temporal calibration for the lithological boundaries in this area (Fig. DR5). Our model uses the Bchron software package (Haslett and Parnell, 2008; Parnell et al., 2008) and is essentially similar to that in Shen et al. (2019a). The model is derived from our U-Pb dates and their stratigraphic positions from the Palougou Section with clear superposition and independent of any correlation assumptions. The lower and upper boundary ages for the Shansi Formation at the Palougou Section are consistent with those at the Qiaotou Section despite the large uncertainties.

Our age model indicates an overall sediment accumulation rate of $22.1 \pm 0.2 \mathrm{~m} / \mathrm{m}$.y. for the Permian succession below the Sunjiagou Formation at the Palougou Section. There is no evidence for any drastic changes in the sediment accumulation rate throughout the succession. This suggests that faster expected sediment accumulation in the red beds of the 
top of the Upper Shihhotse Formation was compensated by depositional gaps.

\section{REFERENCES CITED}

Bowring, J.F., McLean, N.M., and Bowring, S.A., 2011, Engineering cyber infrastructure for U -

$\mathrm{Pb}$ geochronology: Tripoli and U-Pb_Redux: Geochemistry, Geophysics, Geosystems, doi:

10.1029/2010GC003479.

Chu, D.L., Tong, J.N., Song, H.J., Benton, M.J., Bottjer, D.J., Song, H.Y., and Tian, L., 2015, Early

Triassic wrinkle structures on land: stressed environments and oases for life: Scientific

Reports, v. 5, p. 10109, doi: 10.1038/srep10109.

Chu, D.L., Tong, J.N., Benton, M.J., Yu, J.X., and Huang, Y.F., 2019, Mixed continental-marine biotas following the Permian-Triassic mass extinction in South and North China: Palaeogeography, Palaeoclimatology, Palaeoecology, v. 519, p. 95-107, doi: 10.1016/j.palaeo.2017.10.028.

Condon, D.J., Schoene, B., McLean, N.M., Bowring, S.A., and Parrish, R.R., 2015, Metrology and traceability of U-Pb isotope dilution geochronology (EARTHTIME Tracer Calibration Part I): Geochimica et Cosmochimica Acta, v. 164, p. 464-480, doi: 10.1016/j.gca.2015.05.026.

Cope, T., Ritts, B.D., Darby, B.J., Fildani, A., and Graham, S., 2005, Late Paleozoic sedimentation on the northern margin of the North China block: implications for regional tectonics and climate change: International Geology Review, v. 47, p. 270-296, doi: 10.2747/0020- 
6814.47.3.270.

Coutts, D.S., Matthews, W.A., and Hubbard, S.M., 2019, Assessment of widely used methods to derive depositional ages from detrital zircon populations: Geoscience Frontiers, v. 10, p. 1421-1435, doi: 10.1016/j.gsf.2018.11.002.

Haslett, J., and Parnell, A., 2008, A simple monotone process with application to radiocarbon-dated depth chronologies: Journal of the Royal Statistical Society: Series C (Applied Statistics), v. 57, p. 399-418, doi: 10.1111/j.1467-9876.2008.00623.x.

Henderson, C.M., 2018, Permian conodont biostratigraphy, in Lucas, S.G., and Shen, S.Z., eds., The Permian Timescale: Geological Society, London, Special Publications, v. 450, p. 119142, doi: $10.1144 / \mathrm{sp} 450.9$.

Hiess, J., Condon, D.J., McLean, N., and Noble, S.R., 2012, ${ }^{238} \mathrm{U} /{ }^{235} \mathrm{U}$ Systematics in terrestrial Uranium-bearing minerals: Science, v. 335, p. 1610-1614, doi: 10.1126/science.1215507.

Hoke, G.D., Schmitz, M.D., and Bowring, S.A., 2014, An ultrasonic method for isolating nonclay components from clay-rich material: Geochemistry, Geophysics, Geosystems, v. 15, p. 492-498, doi: 10.1002/2013gc005125.

Jaffey, A.H., Flynn, K.F., Glendenin, L.E., Bentley, W.C., and Essling, A.M., 1971, Precision measurement of half-lives and specific activities of $U^{235}$ and $U^{238}$ : Physical Review C, v. 4, p. 1889-1906, doi: 10.1103/PhysRevC.4.1889.

Kong, X.Z., Xu, H.L., Li, R.L., Chang, J.L., Liu, L.J., Zhao, X.H., Zhang, L.X., Liao, Z.T., Zhu, 
H.C., 1996, Late Paleozoic Coal-Bearing Strata and Biota in Shanxi: Taiyuan, China, Science and Technology of Shanxi Press, 280 p.

Lee, K.Y., 1986, Geology of the coal and petroleum deposits in the Ordos basin, China: U.S. Geological Survey Open-File Report 86-278, 63 p.

Li, H.Y., He, B., Xu, Y.G., and Huang, X.L., 2010, U-Pb and Hf isotope analyses of detrital zircons from Late Paleozoic sediments: insights into interactions of the North China Craton with surrounding plates: Journal of Asian Earth Sciences, v. 39, p. 335-346, doi: 10.1016/j.jseaes.2010.05.002.

Li, X.H., Liu, Y., Li, Q.L., Guo, C.H., Chamberlain, K.R., 2009, Precise determination of Phanerozoic zircon $\mathrm{Pb} / \mathrm{Pb}$ age by multicollector SIMS without external standardization: Geochemistry, Geophysics, Geosystems, v. 10, p. 1-21, doi: 10.1029/2009GC002400.

Liu, C., Sun, B.L., and Zeng, F.G., 2014, Constraints on U-Pb dating of detrital zircon of the maximum depositional age for Upper Permian to Lower Triassic strata in Xishan, Taiyuan: Acta Geologica Sinica, v. 88, no. 8, p. 1579-1587 (In Chinese with English Abstract).

Liu, F., Zhu, H.C., and Ouyang, S., 2015, Late Pennsylvanian to Wuchiapingian palynostratigraphy of the Baode section in the Ordos Basin, North China: Journal of Asian Earth Sciences, v. 111, p. 528-552, doi: 10.1016/j.jseaes.2015.06.013.

Liu, G.H., 1990, Permo-Carboniferous paleogeography and coal accumulation and their tectonic control in the North and South China continental plates: International Journal of Coal Geology, v. 16, p. 73-117, doi: 10.1016/0166-5162(90)90014-P. 
Ludwig, K.R., 2012, Isoplot 3.75, A Geochronological Toolkit for Excel: Berkeley Geochronology Center Special Publication, Berkeley, Special Publication, No.5, 75 p.

Luo, S.S., Pan, Z.Y., Lv, Q.Q., He, W.L., and Wen, S., 2017, The upper Paleozoic detrital zircon U$\mathrm{Pb}$ geochronology and its tectonic significance in southwestern Ordos Basin: Geology in China, v. 44, p. 556-574 (In Chinese with English Abstract).

Lv, D.W., and Chen, J.T., 2014, Depositional environments and sequence stratigraphy of the Late Carboniferous-Early Permian coal-bearing successions (Shandong Province, China): Sequence development in an epicontinental basin: Journal of Asian Earth Sciences, v. 79, p. 16-30, doi: 10.1016/j.jseaes.2013.09.003.

Ma, S.X., Meng, Q.R., Duan, L., and Wu, G.L., 2014, Reconstructing Late Paleozoic exhumation history of the Inner Mongolia Highland along the northern edge of the North China Craton: Journal of Asian Earth Sciences, v. 87, p. 89-101, doi: 10.1016/j.jseaes.2014.02.020.

Mattinson, J.M., 2005, Zircon U-Pb chemical abrasion (“CA-TIMS”) method: combined annealing and multi-step partial dissolution analysis for improved precision and accuracy of zircon ages: Chemical Geology, v. 220, p. 47-66, doi: 10.1016/j.chemgeo.2005.03.011.

McLean, N.M., Bowring, J.F., and Bowring, S.A., 2011, An algorithm for U-Pb isotope dilution data reduction and uncertainty propagation: Geochemistry, Geophysics, Geosystems, doi: $10.1029 / 2010 \mathrm{gc} 003478$.

McLean, N.M., Condon, D.J., Schoene, B., and Bowring, S.A., 2015, Evaluating uncertainties in the calibration of isotopic reference materials and multi-element isotopic tracers 
(EARTHTIME Tracer Calibration Part II): Geochimica et Cosmochimica Acta, v. 164, p. 481-501, doi: 10.1016/j.gca.2015.02.040.

Norin, E., 1924, The Litological Character of the Permian Sediments of the Angara Series in Central Shansi, N. China: Geologiska Föreningen Stockholm Förhandlingar, v. 46, p. 19-55, doi: $10.1080 / 11035892409444877$.

Parnell, A.C., Haslett, J., Allen, J.R.M., Buck, C.E., and Huntley, B., 2008, A flexible approach to assessing synchroneity of past events using Bayesian reconstructions of sedimentation history: Quaternary Science Reviews, v. 27, p. 1872-1885, doi: 10.1016/j.quascirev.2008.07.009.

Ramezani, J., Hoke, G.D., Fastovsky, D.E., Bowring, S.A., Therrien, F., Dworkin, S.I., Atchley, S.C., and Nordt, L.C., 2011, High-precision U-Pb zircon geochronology of the Late Triassic Chinle Formation, Petrified Forest National Park (Arizona, USA): Temporal constraints on the early evolution of dinosaurs: Geological Society of America Bulletin, v. 123, p. 2142-2159, doi: 10.1130/B30433.1.

Schaltegger, U., Schmitt, A.K., and Horstwood, M.S.A., 2015, U-Th-Pb zircon geochronology by ID-TIMS, SIMS, and laser ablation ICP-MS: recipes, interpretations, and opportunities: Chemical Geology, v. 402, p. 89-110, doi: 10.1016/j.chemgeo.2015.02.028.

Schmitz, M.D., and Kuiper, K.F., 2013, High-precision geochronology: Elements, v. 9, p. 25-30, doi: 10.2113/gselements.9.1.25.

Shen, S.Z., Ramezani, J., Chen, J., et al., 2019a, A sudden end-Permian mass extinction in South 
China: GSA Bulletin, v. 131, p. 205-223, doi: 10.1130/B31909.1.

Shen, S.Z., Zhang, H., Zhang, Y.C., et al., 2019b, Permian integrative stratigraphy and timescale of China: Science China Earth Sciences, v. 61, p. 154-188, doi: 10.1007/s11430-017-9228-4.

Sheng, J.Z., and Jin, Y.G., 1994, Correlation of Permian deposits in China: Palaeoworld, v. 4, p. 14-113.

Stacey, J.S., and Kramers, J.D., 1975, Approximation of terrestrial lead isotope evolution by a twostage model: Earth and Planetary Science Letters, v. 26, p. 207-221, doi: 10.1016/0012$821 X(75) 90088-6$.

Stevens, L.G., Hilton, J., Bond, D.P., Glasspool, I.J., and Jardine, P.E., 2011, Radiation and extinction patterns in Permian floras from North China as indicators for environmental and climate change: Journal of the Geological Society, v. 168, p. 607-619, doi: 10.1144/0016$76492010-042$.

Sun, J.P., Yang, L., Dong, Y.P., Yang, X.Y., Peng, Y., and Zhao, J., in press, Permian tectonic evolution of the southwestern Ordos Basin, North China: Integrating constraints from sandstone petrology and detrital zircon geochronology: Geological Journal, doi: 10.1002/gj.3916.

Tang, X., Zhang, J.C., Shan, Y.S., and Xiong, J.Y., 2012, Upper Paleozoic coal measures and unconventional natural gas systems of the Ordos Basin, China: Geoscience Frontiers, v. 3, p. 863-873, doi: 10.1016/j.gsf.2011.11.018.

Wan, S.L., and Ding, H., 1987, New discovery in the study of Permo-Carboniferous conodonts in 
North China Platform and its geological significance: Journal of China Coal Society, v. 1, p. 13-16 (In Chinese with English abstract).

Wang, J., 2010, Late Paleozoic macrofloral assemblages from Weibei Coalfield, with reference to vegetational change through the Late Paleozoic Ice-age in the North China Block: International Journal of Coal Geology, v. 83, p. 292-317, doi: 10.1016/j.coal.2009.10.007.

Wang, Y.P., Yang, W.T., Zheng, D.S., Zuo, P.F., and Qi, S.S., 2019, Detrital zircon U-Pb ages from the Middle to Late Permian strata of the Yiyang area, southern North China Craton: Implications for the Mianlue oceanic crust subduction: Geological Journal, v. 54, p. 35273541, doi: 10.1002/gj.3358.

Wang, Z.Q., 1993, Evolutionary ecosystem of Permian-Triassic redbeds in North China: a historical record of global desertification, in Lucas, S.G., and Morales, M., eds., The Nonmarine Triassic: New Mexico Museum of Natural History and Science Bulletin, v. 3, p. 471-476.

Wang, Z.Q., Wang, L.X., 1987, Late Permian fossil plants from the Lower part of the Shiqianfeng (Shihchienfeng) Group in North China: Bulletin of the Tianjin Institute of Geology and Mineral Resources, Chinese Academy of Geological Sciences v. 15, p. 1-80 (in Chinese with English summary).

Wang, Z.H., Qi, Y.P., 2003, Review of Carboniferous-Permian conodont biostratigraphy in North Chian: Acta Micropalaeontologica Sinica, v. 20, p. 225-243 (in Chinese with English abstract).

Wu, Q., Ramezani, J., Zhang, H., Wang, T. T., Yuan, D. X., Mu, L., Zhang, Y. C., Li, X. H., and 
Shen, S. Z., 2017, Calibrating the Guadalupian Series (Middle Permian) of South China: Palaeogeography Palaeoclimatology Palaeoecology, v. 466, p. 361-372, doi: 10.1016/j.palaeo.2016.11.011.

Yan, M.X., Wan, M.L., He, X.Z., Hou, X.D., and Wang, J., 2016, First report of Cisuralian (early Permian) charcoal layers within a coal bed from Baode, North China with reference to global wildfire distribution: Palaeogeography, Palaeoclimatology, Palaeoecology, v. 459, p. 394-408, doi: 10.1016/j.palaeo.2016.07.031.

Yang, D.B., Yang, H.T., Shi, J.P., Xu, W.L., and Wang, F., 2017, Sedimentary response to the paleogeographic and tectonic evolution of the southern North China Craton during the late Paleozoic and Mesozoic: Gondwana Research, v. 49, p. 278-295, doi: 10.1016/j.gr.2017.06.009.

Yang, J.H., Cawood, P.A., Du, Y.S., Feng, B., and Yan, J.X., 2014, Global continental weathering trends across the Early Permian glacial to postglacial transition: Correlating high-and lowpaleolatitude sedimentary records: Geology, v. 42, p. 835-838, doi: 10.1130/G35892.1.

Yang, J.H., Cawood, P.A., Montañez, I.P., Condon, D.J., Du, Y.S., Yan, J.X., Yan, S.Q., and Yuan, D.X., 2020, Enhanced continental weathering and large igneous province induced climate warming at the Permo-Carboniferous transition: Earth and Planetary Science Letters, v. 534, p. 116074, 10.1016/j.eps1.2020.116074.

Yang, J.H., Wu, F.Y., Shao, J.A., Wilde, S.A., Xie, L.W., and Liu, X.M., 2006, Constraints on the timing of uplift of the Yanshan Fold and Thrust Belt, North China: Earth and Planetary 
Science Letters, v. 246, p. 336-352, doi: 10.1016/j.eps1.2006.04.029.

Zhang, S.H., Zhao, Y., Song, B., and Yang, Y.H., 2007, Zircon SHRIMP U-Pb and in-situ Lu-Hf isotope analyses of a tuff from Western Beijing: evidence for missing Late Paleozoic arc volcano eruptions at the northern margin of the North China block: Gondwana Research, v. 12, p. 157-165, doi: 10.1016/j.gr.2006.08.001.

Zhang, Y., Zheng, S.L., and Naugolnykh, S.V., 2012, A new species of Lepidopteris discovered from the Upper Permian of China with its stratigraphic and biologic implications: Chinese Science Bulletin, v. 57, no. 27, p. 3603-3609.

Zhu, X.Q., Zhu, W.B., Ge, R.F., and Wang, X., 2014, Late Paleozoic provenance shift in the southcentral North China Craton: Implications for tectonic evolution and crustal growth: Gondwana Research, v. 25, p. 383-400, doi: 10.1016/j.gr.2013.04.009.

Zhu, Z.C., Liu, Y.Q., Kuang, H.W., Benton, M.J., et al., 2019, Altered fluvial patterns in North China indicate rapid climate change linked to the Permian-Triassic mass extinction: Scientific Reports, v. 9, p. 16818, doi: 10.1038/s41598-019-53321-z. 